\title{
HUBUNGAN PENGETAHUAN DAN SIKAP CLEANING SERVICE TERHADAP TINDAKAN PENGELOLAAN SAMPAH DI WILAYAH PERKANTORAN PROVINSI SULAWESI BARAT
}

\section{ASSOSIATION OF KNOWLEDGE AND ATTITUDE OF CLEANING SERVICE TO WASTE MANAGEMENT ACTIONS IN THE OFFICE AREA OF WEST SULAWESI PROVINCE}

\author{
Siti Rahmah*, Miftah Chairani Hairuddin \\ Jurusan Kesehatan Lingkungan, Poltekkes Kemenkes Mamuju \\ Jalan Poros Mamuju-Kalukku KM 1691511 Mamuju, Sulawesi Barat, Indonesia \\ *email: sitirahmah.akhsan@gmail.com
}

\begin{abstract}
Waste management is an effort to reducing, collecting, moving, temporarily storing, processing and pile up waste. The management that has been happening so far is management in the landfills, while the main problem comes from sources of waste. The objective of this study was to determine correlation of cleaning service behavior (knowledges and attitudes) towards waste management actions in the office area of West Sulawesi Province. This research is an observational study with a cross sectional design conducted in the office area of West Sulawesi Province. The research sample was calculated using the Lemeshow formula so that a sample of 59 people was taken randomly using simple random sampling. The research instrument used a structured questionnaire. Data analysis using the Spearman test. The average knowledge variable is 25,2 (good), the attitude variable is 46,5 (good), and the action variable is 16,1 (good). The bivariate results showed no correlation between knowledge and waste management actions ( $p$-value 0,76, $r: 0,04)$ and no correlation between attitudes and waste management actions ( $p$ value 0,23, $r$ : 0,16). Research result showed respondents understanding of known knowledges and attitudes about waste management was not applied to their actions at work.
\end{abstract}

Keywords: cleaning service, waste management, knowledge, attitude,

\begin{abstract}
Abstrak
Pengelolaan sampah merupakan upaya dalam mengurangi, mengumpulkan, memindahkan, menyimpan sementara, mengolah dan menimbun sampah. Pengelolaan yang selama ini terjadi adalah pengelolaan di Tempat Pemrosesan Akhir (TPA) sampah sedangkan masalah utama berasal dari sumber penghasil sampah. Tujuan penelitian ini untuk mengetahui korelasi perilaku (pengetahuan dan sikap) cleaning service terhadap tindakan pengelolaan sampah di wilayah perkantoran Provinsi Sulawesi Barat. Penelitian ini merupakan penelitian observasional dengan rancang bangun cross sectional yang dilakukan di kawasan perkantoran Provinsi Sulawesi Barat. Sampel penelitian 59 orang yang diambil secara acak menggunakan simple random sampling. Instrumen penelitian menggunakan kuesioner terstruktur. Analisis data menggunakan uji Spearman. Hasil penelitian menunjukkan bahwa rata-rata penilaian terhadap variabel pengetahuan sebesar 25,2 (baik); sikap 46,5 (baik); dan tindakan 16,1 (baik). Hasil uji bivariat menunjukkan tidak ada hubungan antara pengetahuan dengan tindakan pengelolaan sampah (p-value $0,76, \mathrm{r}: 0,04)$ dan tidak ada hubungan antara sikap dengan tindakan pengelolaan sampah ( $p$-value $0,23, \mathrm{r}: 0,16$ ). Hasil penelitian menunjukkan bahwa pemahaman pengetahuan yang telah diketahui dan sikap yang ditunjukkan tentang pengelolaan sampah oleh responden tidak diaplikasikan dalam tindakannya saat bekerja.
\end{abstract}

Kata Kunci : cleaning service, pengelolaan sampah, pengetahuan, sikap 


\section{PENDAHULUAN}

Sampah adalah sisa suatu usaha atau kegiatan yang mengandung bahan berbahaya dan atau beracun yang karena sifat dan konsentrasinya dan atau jumlahnya, baik secara langsung maupun tidak langsung dapat mencemarkan dan merusak lingkungan hidup, kesehatan, kelangsungan hidup manusia serta makhluk hidup lain (Kristanti, 2020). Sampah merupakan salah satu permasalahan kompleks yang dihadapi oleh negara berkembang maupun negara maju di dunia. Masalah sampah merupakan masalah yang umum dan telah menjadi fenomena universal di berbagai negara belahan dunia manapun, dengan titik perbedaannya terletak pada seberapa banyak sampah yang dihasilkan (Chandra, 2012).

Sampah berpengaruh dalam kehidupan manusia terutama pada faktor lingkungan dan faktor perilaku. Faktor perilaku diharapkan dapat memelihara, meningkatkan kesehatan dan melindungi diri dari ancaman penyakit, sedangkan lingkungan diharapkan menciptakan lingkungan yang kondusif, bebas populasi, pemukiman sehat dan pengelolaan sampah yang sehat (Setyowati and Mulasari, 2012). Jumlah sampah semakin meningkat karena adanya aktivitas manusia yang semakin konsumtif perlu ada penanganan untuk mengurangi tumpukan sampah. Sampah bila tidak dikelola dengan baik maka akan menjadi tempat perkembangbiakan vektor penyakit (Saputra and Mulasari, 2017).

Pengelola suatu kawasan diwajibkan untuk dapat mengelola sampah dengan benar dan berwawasan lingkungan, penanganan dengan pemisahan sampah sesuai dengan jenis, jumlah, dan/atau sifat sampah, pengumpulan ke tempat pengolahan sampah terpadu, dan pengolahan dalam bentuk mengubah karakteristik, komposisi, dan jumlah sampah (Arindya, dkk., 2016). Hal tersebut diatur dalam UndangUndang Nomor 8 Tahun 2008 tentang Pengelolaan Sampah.

Pengelolaan sampah merupakan upaya dalam mengurangi, mengumpulkan, memindahkan, menyimpan sementara, mengolah dan menimbun sampah. Pengelolaan sampah perlu melihat bagaimana aliran sampah terjadi. Aliran sampah dimulai dari sumber sampah baik itu rumah tangga, perkantoran, maupun pemukiman, kemudian ke Tempat Penyimpanan Sementara (TPS) dan berakhir di Tempat Pemrosesan Akhir (TPA) (Wardiha, dkk., 2013).
Perkantoran merupakan salah satu sumber penghasil sampah. Kantor Organisasi Tingkat Daerah (OPD) Provinsi Sulawesi Barat di Kabupaten Mamuju terpusat pada satu tempat bersama dengan kantor gubernur. Tempatt tersebut dikenal dengan nama Wilayah Perkantoran Provinsi Sulawesi Barat. Berat jenis sampah pada wilayah perkantoran tersebut berada pada rentang $2.69 \mathrm{~kg} / \mathrm{m}^{3}-6.15 \mathrm{~kg} / \mathrm{m}^{3}$ dan komposisi sampah tertingginya adalah sisa makanan sebesar $4.9 \mathrm{~kg} / \mathrm{hari}$ atau $48.84 \%$ dari total keseluruhan sampah dan tidak dilaksanakan proses pemilahan dan pengolahan sebelum diangkut ke Tempat Pemrosesan Akhir (TPA). Pengelolaan sampah di kantor gubernur dilakukan oleh cleaning service yang berasal dari pihak ketiga (Hairuddin dan Rahmah, 2020).

Pengetahuan dan sikap masyarakat mempunyai hubungan dalam pengelolaan sampah. Pengetahuan baik dalam pengelolaan sampah didukung oleh pendidikan formal dan non formal, bahkan bisa didapatkkan dari media. Sikap masyarakat dalam pengelolaan sampah didukung dari pengetahuan yang diketahuinya (Syam, 2016). Penelitian yang dilakukan oleh A dan Mulasari (2017) pada karyawan di kampus $X$ di Yogyakarta menunjukkan terdapat hubungan antara pengetahuan dengan perilaku pengelolaan sampah sedangkan tidak terdapat hubungan sikap dengan perilaku pengelolaan sampah. Pengetahuan dalam pengelolaan sampah sangat mempengaruhi terjadinya masalah kesehatan. Hal ini menunjukkan bahwa dengan adanya pengetahuan dalam pengelolaan sampah secara baik akan membuat masyarakat paham tentang penyakit yang ditimbulkan oleh sampah (Bisnawati dan Maulina, 2016).

Cleaning service adalah orang yang dalam tugasnya memelihara kebersihan dan memberikan pelayanan kebersihan di suatu tempat atau instansi. Mereka sangat dibutuhkan dalam menciptakan kenyamanan di tempat kerja dan juga termasuk kenyamanan bekerja karyawan dalam hal kebersihan dan pelayanan tempat kerja (Agustina, dkk., 2017). Seorang yang bertugas sebagai cleaning service dalam wilayah perkantoran bertanggung jawab dalam hal pengelolaan sampah. Informasi yang didapatkan dari wawancara awal adalah cleaning service yang bekerja di wilayah perkantoran Provinsi Sulawesi Barat direkrut dari masyarakat yang tinggal di sekitar kantor. Proses perekrutan dilakukan oleh masing-masing kantor yang ada di wilayah perkantoran Provinsi Sulawesi Barat. 
Para cleaning service tersebut tidak diberikan pelatihan sebelum mulai bekerja di kantor tersebut sehingga dapat mempengaruhi cara bekerjanya sehari-hari.

Tujuan dari penelitian ini adalah untuk mengetahui hubungan hubungan pengetahuan dan sikap cleaning service terhadap tindakan pengelolaan sampah di wilayah perkantoran Provinsi Sulawesi Barat.

\section{METODE}

Penelitian ini adalah penelitian observasional dengan rancangan cross sectional. Penelitian dilakukan di kawasan perkantoran Provinsi Sulawesi Barat pada Bulan Mei sampai Agustus 2018. Sampel penelitian dihitung menggunakan rumus sampel simple random sampling Lemeshow didapatkan jumlah sampel sebanyak 59 orang. Cara pengambilan sampel adalah simple random sampling dengan mengacak nama cleaning service yang bekerja di wilayah perkantoran Provinsi Sulawesi Barat setelah terlebih dahulu mengundi nama kantor cleaning service bekerja.

Instrumen penelitian menggunakan kuesioner terstruktur yang merupakan kuesioner buatan sendiri yang telah diuji validitas dan reliabilitasnya dengan jumlah sampe 30 orang. Uji validitas menggunakan teknik Product Moment. $\mathrm{R}$ tabelnya adalah 0,36 dengan signifikansi 0,05 berarti pertanyaan dianggap valid jika nilai $r$ hitung $>0,36$. Sedangkan Uji

reliabilitas menggunakan metode Alpha Cronbach. Apabila suatu variabel menunjukkan nilai Alpha Cronbach >0,60 maka dapat disimpulkan bahwa variabel tersebut dapat dikatakan reliabel atau konsisten dalam mengukur.

Variabel terikat yaitu tindakan pengelolaan sampah sedangkan variabel bebas yaitu pengetahuan dan sikap cleaning service. Analisis data menggunakan uji Spearman karena ketiga variabel tidak terdistribusi nomal. Penelitian ini telah mendapatkan Rekomendasi Persetujuan Etik dari Komisi Etik Penelitian Kesehatan Politeknik Kesehatan Makassar dengan No: 025/KEPK-PTKMKS/II/2018 pada tanggal 7 Februari 2018.

\section{HASIL DAN PEMBAHASAN}

Karakteristik responden pada penelitian ini paling banyak adalah berjenis kelamin perempuan $(64,4 \%)$, berumur $21-30$ tahun $(42,4 \%)$, dan pendidikan terakhir SMA $(57,6$ $\%)$.

Pengetahuan Pengelolaan Sampah
Tingkat pengetahuan responden tentang
pengelolaan sampah diukur dengan
menggunakan kuesioner yang berisi 15
pertanyaan. Pertanayaan tersebut dijawab
berdasarkan wawancara langsung. Data lengkap
mengenai distribusi frekuensi jawaban
responden dapat dilihat pada Tabel 1.

Tabel 1. Distribusi Frekuensi Jawaban Pertanyaan Pengetahuan dan Pertanyaan Tindakan tentang Pengelolaan Sampah

\begin{tabular}{|c|c|c|c|c|}
\hline \multirow{2}{*}{ Pertanyaan } & \multicolumn{2}{|c|}{ Benar } & \multicolumn{2}{|c|}{ Salah } \\
\hline & $\mathbf{n}$ & $\%$ & $\mathbf{n}$ & $\%$ \\
\hline \multicolumn{5}{|l|}{ PERTANYAAN PENGETAHUAN } \\
\hline $\begin{array}{l}\text { Sampah adalah sesuatu bahan atau benda yang sudah tidak dipakai lagi oleh } \\
\text { manusia atau yang sudah tidak dapat digunakan lagi dalam suatu kegiatan? }\end{array}$ & 41 & 69,5 & 18 & 30,5 \\
\hline Apakah pembuangan sampah seharusnya dipisahkan sesuai jenisnya? & 35 & 59,3 & 24 & 40,7 \\
\hline $\begin{array}{l}\text { Apakah sampah harus dipisah pada saat pembuangan berdasarkan mudah } \\
\text { atau tidaknya membusuk? }\end{array}$ & 42 & 71,2 & 17 & 28,8 \\
\hline Apakah sampah sisa makanan termasuk sampah yang mudah membusuk? & 58 & 98,3 & 1 & 1,7 \\
\hline $\begin{array}{l}\text { Apakah sampah kertas dan plastik termasuk sampah yang tidak mudah } \\
\text { membusuk? }\end{array}$ & 48 & 81,4 & 11 & 18,6 \\
\hline Apakah sampah dapat dimanfaatkan kembali? & 44 & 74,6 & 15 & 25,4 \\
\hline Apakah sampah dapat dikurangi sejak dari sumbernya? & 24 & 40,7 & 35 & 59,3 \\
\hline Apakah sampah dapat didaur ulang? & 36 & 61 & 23 & 39 \\
\hline Apakah sampah dapat bernilai ekonomis? & 27 & 45,8 & 32 & 54,2 \\
\hline Apakah anda mengetahui dampak sampah bagi lingkungan? & 21 & 35,6 & 38 & 64,4 \\
\hline Apakah anda mengetahui dampak sampah bagi kesehatan? & 49 & 83,1 & 10 & 16,9 \\
\hline Apakah sampah dapat menyebabkan pencemaran bagi lingkungan? & 22 & 37,3 & 37 & 62,7 \\
\hline Apakah sampah dapat menyebabkan diare? & 55 & 93,2 & 4 & 6,8 \\
\hline $\begin{array}{l}\text { Apakah kita harus menggunakan masker dan sarung tangan pada saat } \\
\text { bekerja? }\end{array}$ & 56 & 94,9 & 3 & 5,1 \\
\hline Apakah kita harus mencuci tangan setelah bekerja? & 45 & 76,3 & 14 & 23,7 \\
\hline
\end{tabular}


Tabel 1 Lanjutan. Distribusi Frekuensi Jawaban Pertanyaan Pengetahuan dan Pertanyaan Tindakan tentang Pengelolaan Sampah

\begin{tabular}{lcccc}
\multicolumn{1}{c}{ Pertanyaan } & Benar & \multicolumn{2}{c}{ Salah } \\
\multicolumn{1}{c}{ PERTANYAAN TINDAKAN } & n & \% & n & \% \\
\hline Menggunakan masker dan sarung tangan saat bekerja & 15 & 25,4 & 44 & 74,6 \\
Memisahkan sampah sesuai jenisnya & 13 & 22 & 46 & 78 \\
Menggunakan tempat sampah yang terbuat dari bahan kedap air & 51 & 86,4 & 8 & 13,6 \\
Menggunakan tempat sampah yang memiliki penutup & 43 & 72,9 & 16 & 27,1 \\
Mengangkut sampah ke Tempat Penampungan Sementara (TPS) 2 kali & 52 & 88,1 & 7 & 11,9 \\
sehari (siang dan sore hari) & 45 & 76,3 & 14 & 23,7 \\
Segera membuang sampah sisa makanan & 45,3 \\
Mengambil tempat sampah baru jika tempat sampah yang digunakan telah & 55 & 93,2 & 4 & 6,8 \\
penuh & 58 & 98,3 & 1 & 1,7 \\
Mengumpulkan sampah yang berserakan & 12 & 79,7 & 12 & 20,3 \\
Mengolah sampah basah menjadi kompos & 13 & 22 & 46 & 78 \\
Mendaur ulang sampah plastik & & & \\
\hline
\end{tabular}

Pada pertanyaan pengetahuan, pertanyaan yang paling banyak jawabannya benar adalah apakah sampah sisa makanan termasuk sampah yang mudah membusuk? $(98,3 \%)$, apakah kita harus menggunakan masker dan sarung tangan pada saat bekerja? $(94,9 \%)$, apakah sampah dapat menyebabkan diare? $(93,2 \%)$, apakah anda mengetahui dampak sampah bagi kesehatan? $(83,1 \%)$, dan apakah sampah kertas dan plastik termasuk sampah yang tidak mudah membusuk? $(81,4 \%)$. Sedangkan pertanyaan yang paling banyak jawabannya salah adalah apakah anda mengetahui dampak sampah bagi lingkungan? $(64,4 \%)$, apakah sampah dapat menyebabkan pencemaran bagi lingkungan? $(62,7 \%)$, dan apakah sampah dapat bernilai ekonomis? $(54,2 \%)$.

Menurut Soekidjo Notoadmojo (2014), pengetahuan adalah hasil tahu dan terjadi setelah seseorang melakukan penginderaan terhadap objek tertentu. Jadi, pengetahuan adalah apa yang telah diperoleh setiap individu setelah melakukan pengamatan atau observasi. Jawaban pada pertanyaan pengetahuan dapat disimpulkan bahwa responden memahami tentang jenis sampah, dampak sampah bagi kesehatan, dan penggunaan Alat Pelindung Diri (APD) saat bekerja. Akan tetapi responden belum memahami tentang dampak sampah bagi lingkungan dan cara pengelolaan sampah sehingga sampah bernilai ekonomis.

Menurut Huclock, dalam Siyoto dan Indasah (2014), semakin cukup umur, tingkat kematangan, dan kekuatan seseorang akan lebih matang dalam berfikir dan bekerja. Begitu juga dengan pendidikan, pendidikan adalah suatu proses penyampaian materi pendidikan oleh pendidik guna mencapai perubahan tingkah laku atau tujuan (Notoadmodjo, 2012). Pendidikan mempunyai hubungan yang signifikan ( $p$-value 0,034) dengan pengelolaan sampah (Sakinah, dkk., 2015). Sehingga dapat diasumsikan bahwa pendidikan yang semakin tinggi akan menambah wawasan, daya tangkap dan pemahaman terhadap informasi yang diterima. Hasil penelitian ini menunjukkan bahwa tingkat pendidikan responden yang paling banyak adalah Sekolah Menengah Atas (SMA) (57,6\%). Maka pengetahuan yang umum tentang sampah seperti jenis sampah, dampak sampah bagi kesehatan, dan penggunaan APD saat bekerja telah diketahui oleh responden.

Pertanyaan tentang pengertian dan jenis sampah sebagian telah dijawab benar oleh responden yang artinya responden telah memahami tentang hal tersebut namun masih ada beberapa responden yang masih menjawab salah pada pertanyaan tentang pemanfaatan kembali sampah. Hal ini menunjukkan bahwa responden telah memahami tentang daur ulang sampah tetapi tidak memahami tentang cara mengerjakannya sehingga sampah dapat bernilai ekonomis. Responden telah memahami tentang dampak sampah bagi kesehatan seperti sampah yang dapat menyebabkan diare $(93,2 \%)$ dan kebiasaan cuci tangan setelah bekerja $(76,3 \%)$. Pertanyaan tentang penggunaan APD saat bekerja sebanyak $94,9 \%$ yang menjawab benar sehingga disimpulkan bahwa responden telah memahami perlunya penggunaan masker dan sarung tangan saat bekerja. Sedangkan pada pertanyaan tentang dampak sampah bagi lingkungan dan sampah dapat menyebabkan pencemaran bagi lingkungan merupakan pertanyaan yang sebagain besar jawabannya salah. 
Pemahaman tentang dampak sampah bagi lingkungan diperlukan karena sampah dapat menjadi bahan pencemar lingkungan. Dampak sampah terhadap kebersihan lingkungan antara lain cairan rembesan sampah yang masuk ke dalam drainase atau sungai akan mencemari air. Penguraian sampah yang dibuang ke dalam air akan menghasilkan asam organik dan gas-cair organik seperti metana. Selain berbau kurang sedap, gas metana dalam konsentrasi tinggi dapat menyebabkan ledakan. Sedangkan dampak terhadap keadaan sosial dan ekonomi adalah pengelolaan sampah yang kurang baik akan membentuk lingkungan yang kurang menyenangkan bagi masyarakat, bau tidak sedap dan pemandangan yang buruk dan tingginya biaya untuk pengolahan air (Safmila daan Risnawati, 2018).

\section{Tindakan Pengelolaan Sampah}

Pengukuran tindakan responden tentang pengelolaan sampah diukur dengan menggunakan kuesioner berisi 10 pernyataan dan disesuaikan tindakan yang dilakukan resposden saat melakukan pekerjaan sehari-hari. Data lengkap mengenai distribusi frekuensi jawaban responden dapat dilihat pada Tabel 1 .

Tindakan yang paling banyak telah dilakukan secara benar oleh responden adalah mengumpulkan sampah yang berserakan $(98,3 \%)$ dan mengambil tempat sampah baru jika tempat sampah yang digunakan telah penuh $(93,2 \%)$. Sedangkan tindakan yang paling banyak responden lakukan dengan cara yang salah adalah memisahkan sampah sesuai jenisnya (78\%) dan mendaur ulang sampah plastik (78\%).

\section{Sikap Pengelolaan Sampah}

Sikap responden tentang pengelolaan sampah diukur dengan menggunakan kuesioner yang berisi 15 pernyataan. Data lengkap mengenai distribusi frekuensi sikap responden dapat dilihat pada Tabel 2.

Tabel 2. Distribusi Frekuensi Jawaban Pernyataan Sikap Tentang Pengelolaan Sampah

\begin{tabular}{|c|c|c|c|c|c|c|c|c|}
\hline \multirow[t]{2}{*}{ Pernyataan } & \multicolumn{2}{|c|}{$\begin{array}{l}\text { Sangat } \\
\text { Setuju }\end{array}$} & \multicolumn{2}{|c|}{ Setuju } & \multicolumn{2}{|c|}{$\begin{array}{l}\text { Tidak } \\
\text { Setuju }\end{array}$} & \multicolumn{2}{|c|}{$\begin{array}{c}\text { Sangat } \\
\text { Tidak } \\
\text { Setuju }\end{array}$} \\
\hline & $\mathbf{n}$ & $\%$ & $\mathbf{n}$ & $\%$ & $\mathbf{n}$ & $\%$ & n & $\%$ \\
\hline $\begin{array}{l}\text { Menggunakan masker dan sarung tangan pada saat } \\
\text { bekerja }\end{array}$ & 34 & 57,6 & 24 & 40,7 & 1 & 1,7 & 0 & 0 \\
\hline Saya mengumpulkan sampah berdasarkan jenisnya & 10 & 16,9 & 32 & 54,2 & 17 & 28,8 & 0 & 0 \\
\hline $\begin{array}{l}\text { Saya mengumpulkan sampah saat siang dan sore } \\
\text { hari }\end{array}$ & 27 & 45,8 & 28 & 47,5 & 3 & 5,1 & 1 & 1,7 \\
\hline $\begin{array}{l}\text { Mengumpulkan sampah menggunakan tempat } \\
\text { sampah kedap air }\end{array}$ & 16 & 27,1 & 24 & 40,7 & 15 & 25,4 & 4 & 6,8 \\
\hline Tempat sampah harus memiliki penutup & 35 & 59,3 & 23 & 39 & 1 & 1,7 & 0 & 0 \\
\hline $\begin{array}{l}\text { Mengangkut sampah sebelum tempat sampah } \\
\text { penuh }\end{array}$ & 27 & 45,8 & 24 & 40,7 & 8 & 13,6 & 0 & 0 \\
\hline Sampah dapat didaur ulang & 25 & 42,4 & 31 & 52,5 & 2 & 3,4 & 1 & 1,7 \\
\hline $\begin{array}{l}\text { Sampah dapat dikurangi sejak dari sumber } \\
\text { penghasil sampah }\end{array}$ & 15 & 25,4 & 33 & 55,9 & 10 & 16,9 & 1 & 1,7 \\
\hline Sampah dapat digunakan kembali & 18 & 30,5 & 26 & 44,1 & 13 & 22 & 2 & 3,4 \\
\hline Mencuci tangan setelah bekerja & 25 & 42,4 & 19 & 32,2 & 12 & 20,3 & 3 & 5,1 \\
\hline Sampah basah dapat dimanfaatkan sebagai kompos & 18 & 30,5 & 26 & 44,1 & 13 & 22 & 2 & 3,4 \\
\hline Sampah plastik dapat didaur ulang & 23 & 39 & 32 & 54,2 & 3 & 5,1 & 1 & 1,7 \\
\hline Membakar sampah adalah sikap yang baik & 26 & 44,1 & 19 & 32,2 & 13 & 22 & 1 & 1,7 \\
\hline Pembakaran sampah dapat mencemari lingkungan & 15 & 25,4 & 26 & 44,1 & 17 & 28,8 & 1 & 1,7 \\
\hline $\begin{array}{l}\text { Sampah yang berserakan dapat mengganggu } \\
\text { keindahan }\end{array}$ & 29 & 49,2 & 20 & 33,9 & 10 & 16,9 & 0 & 0 \\
\hline
\end{tabular}

Tabel 2 menunjukkan penyataan yang paling banyak mendapat tanggapan sangat setuju adalah tempat sampah harus memiliki penutup $(59,3 \%)$, pernyataan yang paling banyak mendapat tanggapan setuju adalah sampah dapat dikurangi sejak dari sumber $(55,9 \%)$, pernyataan yang paling banyak mendapat tanggapan tidak setuju adalah saya mengumpulkan sampah berdasarkan jenisnya dan pembakaran sampah dapat mencemari lingkungan $(28,8 \%)$, dan pernyataan yang paling banyak mendapat tanggapan sangat tidak setuju adalah mengumpulkan sampah menggunakan tempat sampah kedap air $(6,8 \%)$. 


\section{Analisis Bivariat antara Pengetahuan dan Sikap Responden terhadap Tindakan Pengelolaan Sampah}

Nilai rata-rata merupakan ukuran pemusatan data yang menggambarkan kisaran data tersebut dengan membagi jumlah data dengan banyaknya data (Sabri dan Hastono, 2018). Nilai rata-rata variabel pengetahuan adalah 25,2; sikap 46,5; dan tindakan 16,1 . Nilai tersebut berarti kisaran nilai jawaban variabel pengetahuan berada pada angka 25,2, kisaran nilai jawaban variabel sikap berada pada angka 46,5, dan kisaran nilai jawaban variabel tindakan berada pada angka 16,1. Nilai tersebut baik karena mendekati nilai tertinggi.

Nilai standar deviasi merupakan variasi sebaran data. Semakin kecil nilai sebarannya berarti variasi nilai data makin sama. Semakin besar nilai sebarannya berarti data semakin bervariasi. Jika sebarannya bernilai 0 , maka nilai semua datanya adalah sama (Sabri dan Hastono, 2018). Nilai standar deviasi variabel pengetahaun adalah 2,3, variabel sikap adalah
4,9, dan variabel tindakan adalah 1,3. Nilai tersebut berarti variabel sikap mempunyai variasi data yang lebih bervariasi dibandingkan variabel pengetahuan dan variabel tindakan.

Nilai median adalah angka tengah pada kelompok data yang digunakan untuk pemusatan data (Dahlan, 2019). Nilai median variabel pengetahuan sebesar 26, variabel sikap sebesar 46, dan variabel tindakan sebesar 16 .

Uji bivariat dilakukan untuk melihat korelasi variabel tindakan dengan pengetahuan dan sikap. Korelasi tersebut dinilai dari arah korelasi, besarnya korelasi, serta kemaknaannya (Dahlan, 2019). Kekuatan atau besarnya korelasi dapat dilihat dari besarnya nilai korelasi (nilai r). Jika memiliki nilai antara 0-0,2 kekuatan korelasinya sangat lemah, $>0,2-0,4$ lemah, $>0,4-$ 0,6 sedang, $>0,6-0,8$ kuat, dan $>0,8$ sangat kuat. Nilai $\mathrm{p}$ berhubungan dengan kemaknaan uji korelasi yang telah dilakukan. Jika nilai $\mathrm{p}<0,05$ (nilai alpha) maka uji korelasi yang dilakukan bermakna secara statistik (Dahlan, 2019). Hasil uji bivariat dapat dilihat pada Tabel 3 .

Tabel 3. Hasil Analisis Bivariat

\begin{tabular}{lcccc}
\hline \multicolumn{1}{c}{ Nama Variabel } & $\mathbf{N}$ & $\boldsymbol{p}$-value & $\mathbf{r}$ & Arah \\
\hline Pengetahuan - Tindakan & 59 & 0,76 & 0,04 & Positif \\
Sikap - Tindakan & 59 & 0,23 & 0,16 & Positif \\
\hline
\end{tabular}

Hubungan antara Pengetahuan terhadap Tindakan Pengelolaan Sampah

Variabel pengetahuan memiliki nilai $p$ value sebesar 0,76 yang artinya tidak ada hubungan (korelasi) antara pengetahuan dengan tindakan responden pada penelitian ini. Nilai korelasi (r) sebesar 0,04 menunjukkan korelasi sangat lemah antara pengetahuan dan tindakan dengan arah korelasi yang menunjukkan arah positif atau searah artinya semakin besar nilai pengetahuan maka semakin besar pula nilai tindakan. Hal tersebut memang terlihat dari pemahaman pengetahuan tentang pengelolaan sampah yang telah diketahui oleh responden namun tidak diaplikasikan dalam tindakan saat bekerja. Sebagian besar responden tidak memisahkan sampah sesuai jenisnya walaupun telah mengetahui jenis sampah. Tindakan tersebut terjadi karena tidak disediakannya tempat sampah sesuai jenis sampah di tempat kerja. Semua tempat kerja menyediakan tempat sampah kecil di setiap ruangan, namun hanya berjumlah satu unit dan tidak ada keterangan jenis sampah di tempat sampah tersebut. Pada tempat sampah besar juga tidak ada keterangan untuk jenis sampah sehingga cleaning service tidak memisahkan sampah sesuai jenisnya.
Begitupun dengan responden yang memahami tentang penggunaan APD namun sebagian besar responden tidak menggunakan masker dan sarung tangan saat bekerja. Hal tersebut terjadi karena pihak kantor tidak menyediakan APD untuk cleaning service sehingga cleaning service tidak menggunakan masker dan sarung tangan saat bekerja. Manfaat penggunaan APD saat bekerja adalah melindungi cleaning service dari penyakit akibat kerja yang ditimbulkan oleh sampah, seperti penyakit kulit. Bakteri, virus, dan jamur dari sampah dapat menginfeksi dan merusak kulit. Kejadian tersebut telah banyak terjadi seperti penelitian yang dilakukan terhadap petugas kebersihan di pasar tradisional Penampungan Pusat Pasar Kota Medan menunjukkan bahwa sebanyak $36,4 \%$ responden pernah mengalami keluhan iritasi kulit (Wijayanti, 2015) dan penelitian pekerja daur ulang sampah plastik di Kota Bau - Bau yang menunjukkan bahwa ada hubungan penggunaan APD dengan keluhan penyakit kulit pada pekerja (Andriani, Hudayah and Hasmina, 2020).

Kedua situasi tersebut menggambarkan terbatasnya fasilitas yang disediakan di tempat kerja sehingga cleaning service yang memiliki 
pemahaman yang bagus tidak didukung dengan fasilitas sehingga tidak bisa melaksanakan hal yang dipahami oleh cleaning service saat bekerja. Upaya untuk mendukung pelaksanaan pengelolaan sampah secara maksimal adalah dengan memperhatikan sarana dan prasarana yang menunjang pengelolaan sampah (Hutabarat, Ottay and Siagian, 2015). Semua hal tersebut perlu menjadi perhatian tempat kerja sehingga dapat memaksimalkan tindakan para cleaning service dalam melakukan pengelolaan sampah yang baik.

Penelitian ini sejalan dengan penelitian Agustina yang menyatakan tidak ada korelasi pengetahuan dengan tindakan pengelolaan sampah pada petugas kebersihan di Puskesmas Kota Banjarbaru (Agustina, dkk., 2017). Begitu juga dengan penelitian Doa yang juga menyatakan tidak ada hubungan antara pengetahuan dengan pengelolaan sampah rumah tangga di Desa Borgo (Doa, dkk., 2017).

Perrnyataan tentang penggunaan APD paling banyak direspon dengan sangat setuju oleh responden. Penyataan tentang pengelolaan sampah seperti pemilahan sampah, pengumpulan, pengangkutan, dan pemanfaatan kembali juga ditanggapi dengan respon positif oleh responden. Pernyataan tentang pemilahan sampah sebagian besar direspon setuju jadi respoden sudah cenderung untuk menerima bahwa sampah dikumpulkan berdasarkan jenisnya dan sampah dikumpulkan saat siang dan sore hari. Pernyataan tentang pengumpulan sampah sebagian besar direspon setuju tapi pada pernyataan menggunakan tempat sampah kedap air mendapat respon yang bervariasi dari responden, bahkan terdapat $6,8 \%$ yang merespon sangat tidak setuju.

Pernyataan tentang pengangkutan sampah direspon sangat setuju oleh responden yang artinya responden telah menerima untuk mengangkut sampah sebelum tempat sampah penuh sehingga sampah tidak berserakan. Respon tersebut sejalan dengan pernyataan bahwa sampah berserakan dapat menganggu keindahan yang paling banyak direspon sangat setuju oleh responden (49,2\%). Pernyataan tentang pemanfaatan kembali sampah sebagian besar direspon setuju yang artinya mereka setuju untuk mendaur ulang sampah. Pernyataan tentang pengolahan sampah direspon berbedabeda, terutama pada penyataan tentang membakar sampah. Respon dari responden menunjukkan sangat setuju $(44,1 \%)$ pada pernyataan membakar sampah adalah sikap yang baik tapi pada pernyataan bahwa pembakaran sampah dapat mencemari lingkungan paling banyak direspon setuju $(44,1 \%)$ oleh responden.

Pembakaran sampah memang tidak disarankan menjadi cara pengolahan sampah. Kegiatan membakar sampah akan menghasilkan gas CO (karbonmonoksida). Gas CO mudah bereaksi dengan darah membentuk ikatan karboksihemoglobin $(\mathrm{COHb})$ yang membuat fungsi darah sebagai pengangkut oksigen terganggu. Selain itu, pembakaran sampah juga menghasilkan gas $\mathrm{CH}_{4}$ (metana). Metana merupakan jenis pencemar yang tidak berbau, tidak berwarna namun mudah terbakar. Metana termasuk ke dalam gas rumah kaca kedua yang paling penting. Metana memiliki sifat $72 \mathrm{kali}$ lebih kuat daripada $\mathrm{CO}_{2}$ dalam hal menyerap panas di dalam atmosfer. Kehadiran gas metana sangat berpengaruh dalam meningkatkan gas rumah kaca yang berakibat kepada pemanasan global (Jati, 2015).

\section{Hubungan antara Sikap Responden terhadap Tindakan Pengelolaan Sampah}

Variabel sikap memiliki nilai $p$-value sebesar 0,23 yang artinya tidak ada hubungan (korelasi) antara sikap dengan tindakan responden pada penelitian ini. Nilai korelasi (r) sebesar 0,6 menunjukkan korelasi sangat lemah antara sikap dan tindakan. Arah korelasi (tren) menunjukkan arah yang positif atau searah artinya semakin besar nilai sikap maka semakin besar pula nilai tindakan. Hal tersebut dapat dilihat dari pernyataan tentang daur ulang yang paling banyak direspon setuju namun para cleaning sevice tidak melakukannya pada tindakan. Hal tersebut terjadi karena responden tidak tahu cara mengolah atau memanfaatkan kembali sampah sehingga dapat bernilai ekonomis. Sampah anorganik seperti plastik, kertas, kardus, kaleng, besi, dan logam merupakan sampah yang dapat dimanfaatkan kembali (daur ulang). Sampah tersebut dapat dikumpulkan kemudian dibuat menjadi kerajinan tangan yang dapat dijual kembali. Sedangkan sampah organik dapat dimanfaatkan menjadi kompos untuk menjadi pupuk tanaman (Sakinah, dkk., 2015).

Penelitian ini sejalan dengan penelitian Numan yang menyatakan tidak ada hubungan antara sikap dengan pengelolaan sampah rumah tangga di Perumahan Permata Puri Kelurahan Beringin Kecamatan Ngaliyan Semarang (Numan, 2015). Selain itu, penelitian ini juga sejalan dengan penelitian Mulasari yang 
menyatakan tidak ada hubungan antara sikap dengan perilaku pengelolaan sampah pada kayawan kampus X di Yogyakarta (A dan Mulasari, 2017).

\section{KESIMPULAN DAN SARAN}

\section{Kesimpulan}

Kesimpulan dari penelitian ini adalah tidak ada hubungan antara pengetahuan dan sikap terhadap tindakan pengelolaan sampah pada cleaning service di wilayah perkantoran Provinsi Sulawesi Barat

\section{Saran}

Saran yang dapat direkomendasikan berdasarkan hasil penelitian ini adalah tempat kerja memberikan pelatihan terkait pengelolaan sampah, khususnya tentang pemanfaatan sampah 3R (Reuse, Reduce, dan Recycle), kepada para cleaning service sebelum mulai bekerja agar ilmu yang didapatkan dapat diaplikasikan saat bekerja. Selain itu, tempat kerja juga dapat menyediakan fasilitas untuk pengelolaan sampah seperti APD saat bekerja (masker dan sarung tangan) dan tempat sampah yang berbeda berdasarkan jenis sampah.

\section{UCAPAN TERIMA KASIH}

Terima kasih disampaikan kepada Direktur Poltekkes Kemenkes Mamuju atas pemberian ijin dan pembiayaan terhadap penelitian ini, pemerintah Provinsi Sulawesi Barat yang telah mengizinkan melakukan penelitian dan responden yang berpartisipasi dalam penelitian ini.

\section{DAFTAR PUSTAKA}

1] Agustina, N., Irianty, H. and Wahyudi, N. T. (2017) 'Hubungan Karakteristik Petugas Kebersihan Dengan Pengelolaan Sampah di Puskesmas Kota Banjarbaru', Jurnal Publikasi Kesehatan Masyarakat Indonesia, 4(2), pp. 62-66.

2] Andriani, R., Hudayah, N. and Hasmina, H. (2020) 'Hubungan Penggunaan Alat Pelindung Diri (APD) dengan Keluhan Penyakit Kulit pada Pekerja Daur Ulang Sampah Plastik Kamboja di Kecamatan Wolio Kota Baubau', Jurnal Kesehatan Global, 3(2), pp. 69-75. doi: $10.33085 / \mathrm{jkg} . \mathrm{v} 3 \mathrm{i} 2.4648$.

3] Arindya, Y., Oktiawan, W. and Zaman, B.
(2016) 'Technical Study of Generation, Composition, and Characteristics as well as Waste Management Plans, Faculty of Engineering, University of Diponegoro', Journal of Environmental Engineering, 5(1), pp. 1-10.

4] Bisnawati, B. and Maulina, M. (2016) 'Pengetahuan Masyarakat Dalam Pengelolaan Sampah', Jurnal Ilmiah Mahasiswa Fakultas Keperawatan, 1(1), pp. 1-4.

5] Chandra, B. (2012) Pengantar Kesehatan Lingkungan. Jakarta: EGC.

6] Dahlan, M. S. (2019) Statistik untuk Kedokteran dan Kesehatan. Jakarta: Salemba Medika.

7] Dian Rahayu Jati, D. O. Y. F. (2015) 'Analisis Beban Emisi Co Dan Ch4 Dari Kegiatan Pembakaran Sampah Rumah Tangga Secara Terbuka (Studi Kasus Kecamatan Sungai Kakap, Kabupaten Kubu Raya)', Jurnal Teknologi Lingkungan Lahan Basah, 3(1), pp. 1-10. doi: 10.26418/jtllb.v3i1.12863.

8] Doa, Y. C., Umboh, J. M. L. and Maramis, F. R. R. (2017) 'Hubungan Antara Pengetahuan dan Sikap Dengan Tindakan Ibu Rumah Tangga Dalam Pengelolaan Sampah Rumah Tangga di Desa Borgo Kecamatan Tombariri Kabupaten Minahasa', Jurnal IKMAS, 2(5), pp. 1-6.

9] Hairuddin, M. C. and Rahmah, S. (2020) 'Analisis Timbulan Sampah di Kantor Gubernur Provinsi Sulawesi Barat', Jurnal Publikasi Kesehatan Masyarakat Indonesia, 7(1), p. 34. doi: 10.20527/jpkmi.v7i1.8791.

10] Hutabarat, B. T. F., Ottay, R. I. and Siagian, I. (2015) 'Gambaran Perilaku Masyarakat Terhadap Pengelolaan Sampah Padat Di Kelurahan Malalayang Ii Kecamatan Malalayang Kota Manado', Jurnal Kedokteran Komunitas Dan Tropik, 3(1), pp. 41-47.

11] Kristanti, I. (2020) 'Hubungan Pengetahuan Dan Sikap Tentang Pengelolaan Sampah Dengan Perilaku Pembuangan Sampah', Jurnal Kesehatan, 8(2), pp. 991-997. doi: 10.38165/jk.v8i2.108.

12] Notoadmodjo, S. (2012) Promosi Kesehatan dan Ilmu Perilaku. Jakarta: 
Rineka Cipta.

13] Notoadmodjo, S. (2014) Ilmu Perilaku Kesehatan. Jakarta: Rineka Cipta.

14] Nu'man, A. N. (2015) Faktor - Faktor yang Mempengaruhi Pengelolaan Sampah Rumah Tangga di Perumahan Bukit Permata Suri Kelurahan Beringin Kecamatan Ngaliyan Kota Semarang Tahun 2015. Univesitas Dian Nuswantoro.

15] Sabri, L. and Hastono, S. P. (2018) Statistik Kesehatan. Jakarta: Rajawali Pres.

16] Safmila, Y. and Risnawati (2018) 'Hubungan Kebersihan Lingkungan Dan Pencemaran Udara Dengan Tanggapan Masyarakat Terhadap Keberadaan Tempat Pembuangan Akhir Sampah (TPA) Banda Aceh', Majalah Kesehatan Masyarakat Aceh (Makma), 1(2), pp. 79-85.

17] Sakinah, Erna and Marta (2015) 'Hubungan Pengetahuan, Sikap Dan Pendidikan Ibu Rumah Tangga Dengan Pengelolaan Sampah Rumah Tangga Di Dusun Semambu Bunting Kelurahan Jambi Kecil Kecamatan Muaro Sebo Tahun 2014', Scientia Journal, 4(1), pp. 22-28.

18] Saputra, S. and Mulasari, S. A. (2017) 'Pengetahuan, Sikap, dan Perilaku Pengelolaan Sampah pada Karyawan di Kampus', Kes Mas: Jurnal Fakultas Kesehatan Masyarakat Universitas Ahmad Daulan, 11(1), pp. 22-27. doi: 10.12928/kesmas.v11i1.4212.
19] Setyowati, R. and Mulasari, S. A. (2012) 'Pengetahuan dan Perilaku Ibu Rumah Tangga Dalam Pengelolaan Sampah Plastik', Jurnal Kesehatan Masyarakat Nasional, 7(12), pp. 562-566. doi: 10.21109/kesmas.v7i12.331.

20] Siyoto, S. and Indasah (2014) 'Keterkaitan Pengetahuan dan Perilaku Petugas Kebersihan Dalam Penanganan Sampah di Hotel Kediri', Indonesian Journal of Nutritional Epidemiology and Reproductive, 3(2), pp. 85-92.

21] Syam, D. M. (2016) 'Hubungan Pengetahuan Dan Sikap Masyarakat Dengan Pengelolaan Sampah Di Desa Loli Tasiburi Kecamatan Banawa Kabupaten Donggala', HIGIENE: Jurnal Kesehatan Lingkungan, 2(1), pp. 21-26.

22] Wardiha, M. W. et al. (2013) 'Waste Generation and Composition in Office and Wisma Areas (Case Study: Werdhapura Village Center, Denpasar City, Bali Province)', Journal of Presipitasi, 10(1), pp. 7-17.

23] Wijayanti, D. F. (2015) 'Hubungan Pengetahuan, Sikap, dan Tindakan Penggunaan Alat Pelindung Diri Terhadap Keluhan Gangguan Kulit Pada Petugas Sampah TPA Batu Layang Pontianak', Jurnal Mahasiswa PSPD FK Universitas Tanjungpura, 3(1), pp. 1-19. 